SUSTAINABLE FORESTRY

COLLECTION 81-82, 2020
ODRŽIVO ŠUMARSTVO

ZBORNIK RADOVA 81-82, 2020

UDK 630*443.3:582.475(497.11 Avala $)=111$

Original scientific paper

\title{
THE MOST IMPORTANT MYCOSES OF AUSTRIAN PINE (PINUS NIGRA ARNOLD.) IN THE AVALA AREA
}

\author{
Zlatan RADULOVIĆ ${ }^{\prime}$, Aleksandar LUČIĆ ${ }^{l}$, Katarina MLADENOVIĆ ${ }^{l}$, \\ Ivan MILENKOVIĆ
}

\begin{abstract}
Austrian pine is one of the species most often used for afforestation in our conditions. In the area of Avala, afforestation with Austrian and Scots pine began in 1899. The stands of Austrian pine located on the northern and northwestern foothills of the Avala Landscape of Outstanding Features are 115 years old, while the stands on the southern and southeastern side are about 65 years old. Two-year research in the area of Avala recorded the presence of 18 species of fungi on Austrian pine. Out of that number, 6 fungi were found on needles, 5 on needles and seeds, 2 on roots and stem bases, 1 on cones, 3 on trunks and branches and 1 species in vascular bundles. Of all the species, the greatest damage is caused by Sphaeropsis sapinea and species of the Armillaria genus.
\end{abstract}

Keywords: Austrian pine, mycoses, fungi, Avala

\section{NAJVAŽNIJE MIKOZE CRNOG BORA (PINUS NIGRA ARNOLD.) NA PODRUČJU AVALE}

Izvod: Crni bor je jedna od vrsta koja se u našim uslovima najčešće koristi za pošumljavanje. Na području Avale pošumljavanja crnim i belim borom počela su još 1899 godine. Sastojine crnog bora koje se nalaze na severnoj i severozapadnoj strani podnožja PIO Avala su starosti 115 godina, dok su sastojine koje se nalaze na južnoj i jugoistočnoj strani starosti oko 65 godina. Tokom dvogodišnjih istraživanja na području Avale na crnom boru je zabeleženo prisustvo 18 vrsta gljiva. Na četinama konstatovano je prisustvo 6 gljiva, na četinama i semenu 5, na korenu i pridanku 2, na šišaricama 1, deblu i granama $3 i$ u

\footnotetext{
${ }^{1}$ dr Zlatan Radulović, senior research associate, Institute of Forestry, Belgrade, Serbia, dr Aleksandar Lučić, senior research associate, Institute of Forestry, Belgrade, Serbia, dr Katarina Mladenović, research associate, Institute of Forestry, Belgrade, Serbia

${ }^{2}$ dr Ivan Milenković, assistant professor, University of Belgrade, Faculty of Forestry, Belgrade, Serbia
} 
sprovodnim sudovima 1 vrsta. Od svih vrsta najveće štete pričinjavaju Sphaeropsis sapinea $i$ vrste roda Armillaria.

Ključne reči: crni bor, mikoze, gljive, Avala

\section{INTRODUCTION}

Avala, the northernmost mountain in Šumadija, stands out in the wider area of Belgrade with its altitude of 506 meters. By the decision of the City of Belgrade of 2007, Avala was protected as a Landscape of Outstanding Features. It belongs to the Šumadija Mountain Range that represent a transitional zone between the Dinaric and Rhodope mountain ranges.

The area of the protected natural asset is characterized by the diversity and abundance of plant species. The recent flora of Avala consists of about 600 plant species from two classes, 86 families and 317 genera. A total of 6 forest and 4 meadow communities have been recognized and described on Mt.Avala. In the period from 1899 to 1906, Austrian and Scots pine plantations were established to replace clearings and thickets (Obratov-Petković, D., Đukić, M., 2000).

The family Pinaceae contains 11 genera, with 195 species of trees and infrequent shrubs. The Pinaceae family has the following three subfamilies: Abietoideae, Pinoideae, and Laricioideae. The Pinoideae subfamily includes only the Pinus genus, which is divided into 2 subgenera: Pinus and Strobus. Austrian pine belongs to the Pinaceae family, Pinoideae subfamily and Pinus genus and subgenus. Austrian pine is native to southern Europe, northwestern Africa, and western Asia. It belongs to the sub-Mediterranean floral element. In Serbia, it is found in the northwestern and central parts, and not so often in eastern Serbia. Earlier research identified several subspecies, but recent research has shown that there are only two subspecies, of which only ssp. nigra grows in Serbia (Cvjetićanin, R., et al., 2016).

In his research, Farjon, A. (2017) determines 5 subspecies of Austrian pine: Pinus nigra ssp. nigra (native to the east of Austria, north of Italy, Balkan Peninsula, Bulgaria, Romania, and the European portion of Turkey), Pinus nigra ssp. laricio (Corsica in France, southern Apennines and Sicily in Italy), Pinus nigra ssp. pallasiana (Kütahya Province in Turkey), Pinus nigra ssp. dalmatica (Croatia) and Pinus nigra ssp. salzmannii (southwestern Europe, Heraulz and Pyrenees in France, Spain, the region of Diebel Djurdur in Algeria, and the Rif Mountain Range in the north of Morocco).

Austrian pine is one of the species most often used for afforestation in our conditions. Its needles are dark green. It forms a wide crown and reaches large dimensions. Austrian pine prefers bright and warm exposures and is very resistant to adverse environmental conditions. It grows well on all soil types, even on extremely poor and shallow soils. Apart from being drought-prone and wind-resistant, it tolerates urban conditions.

Austrian pine in PA Avala is located in five compartments and 11 sections, on the northern and southern slopes. It builds pure or mixed stands. The stands of Austrian pine on the northern and northwestern foothills of Avala are 117 years old and the stands on the southern and southeastern side are about 67 years old. 


\section{MATERIAL AND METHOD}

The research was conducted during 2018 and 2019 in the area of PA Avala in compartment 15 (section i), compartment 21 (sections a, b, c, d, e), compartment 23 (sections d, h), compartment 25 (sections k, n), and compartment 29 (section a).

The visual appearance of fruiting body was used in the identification of species. When it was not possible, the material with disease symptoms was transferred to the laboratory, where it was analyzed using standard phytopathological methods.

Tissues from which the material was isolated were first washed with running water for at least 30 minutes. Fungi were isolated from the freshly infected parts of lesion tissue which were cut into pieces smaller than $5 \mathrm{~mm}$. Saprophytic species were isolated from older infected tissues. The pieces of excised tissue were surfacesterilized in sodium hypochlorite solution (2-6\% active chlorine) for 2 minutes or in $70 \%$ ethanol for a few seconds and then washed in sterile distilled water. They were then transferred to appropriate nutritional media under aseptic conditions. Petri dishes were put into an incubator at appropriate temperatures, and the suitable time for species identification was determined through daily observation. Fungus cultures usually grew at temperatures between 21 and $25^{\circ} \mathrm{C}$, but sometimes they were incubated at lower temperatures (below $15^{\circ} \mathrm{C}$ ) or higher temperatures (above $34^{\circ} \mathrm{C}$ ).

The formation of fruiting bodies was accelerated by changing external conditions (temperature, light regime), nutrition of fungi (replacement of nutrientrich media with water-agar media), or long-term culture development. Identification was usually performed based on the culture characteristics, as well as morphological and physiological characteristics of the fungus using the following keys: Bondarceva, M. A. (1998), Dennis, R. W. G. (1978), Ellis, M., B., Ellis, J., B. (1985), Lanier, L., et. al. (1978), Minter, W.D. (1981) and Sutton B.C. (1980). The classification of fungi was performed according to the database available at www.indexfungorum.org/Names/Names.asp.

\section{RESULTS AND DISCUSSION}

The species of fungi identified on Austrian pine in the area of Avala are shown in Table 1.

Table 1. Fungus species identified on Austrian pine in the area of Avala

\begin{tabular}{|l|l|l|c|}
\hline Latin name & Classification & Affected plant part & Significance \\
\hline Alternaria alternata (Fr.) Kassler & Ascomycota, Pleosporaceae & Older needles, seed & + \\
\hline Armillaria spp. & $\begin{array}{l}\text { Basidiomycota, } \\
\text { Physalacriaceae }\end{array}$ & Root and stem base & +++ \\
\hline Auriscalpium vulgare Gray & $\begin{array}{l}\text { Basidiomycota, } \\
\text { Auriscalpiaceae }\end{array}$ & Fallen cones & + \\
\hline Botrytis cinerea Pers. ex Fr. & $\begin{array}{l}\text { Ascomycota, } \\
\text { Sclerotiniaceae }\end{array}$ & $\begin{array}{l}\text { Needles, shoots, and } \\
\text { seed }\end{array}$ & + \\
\hline Ceratocystis spp. & $\begin{array}{l}\text { Ascomycota, } \\
\text { Ceratocystidaceae }\end{array}$ & $\begin{array}{l}\text { Vascular bundles of } \\
\text { stems }\end{array}$ & ++ \\
\hline
\end{tabular}




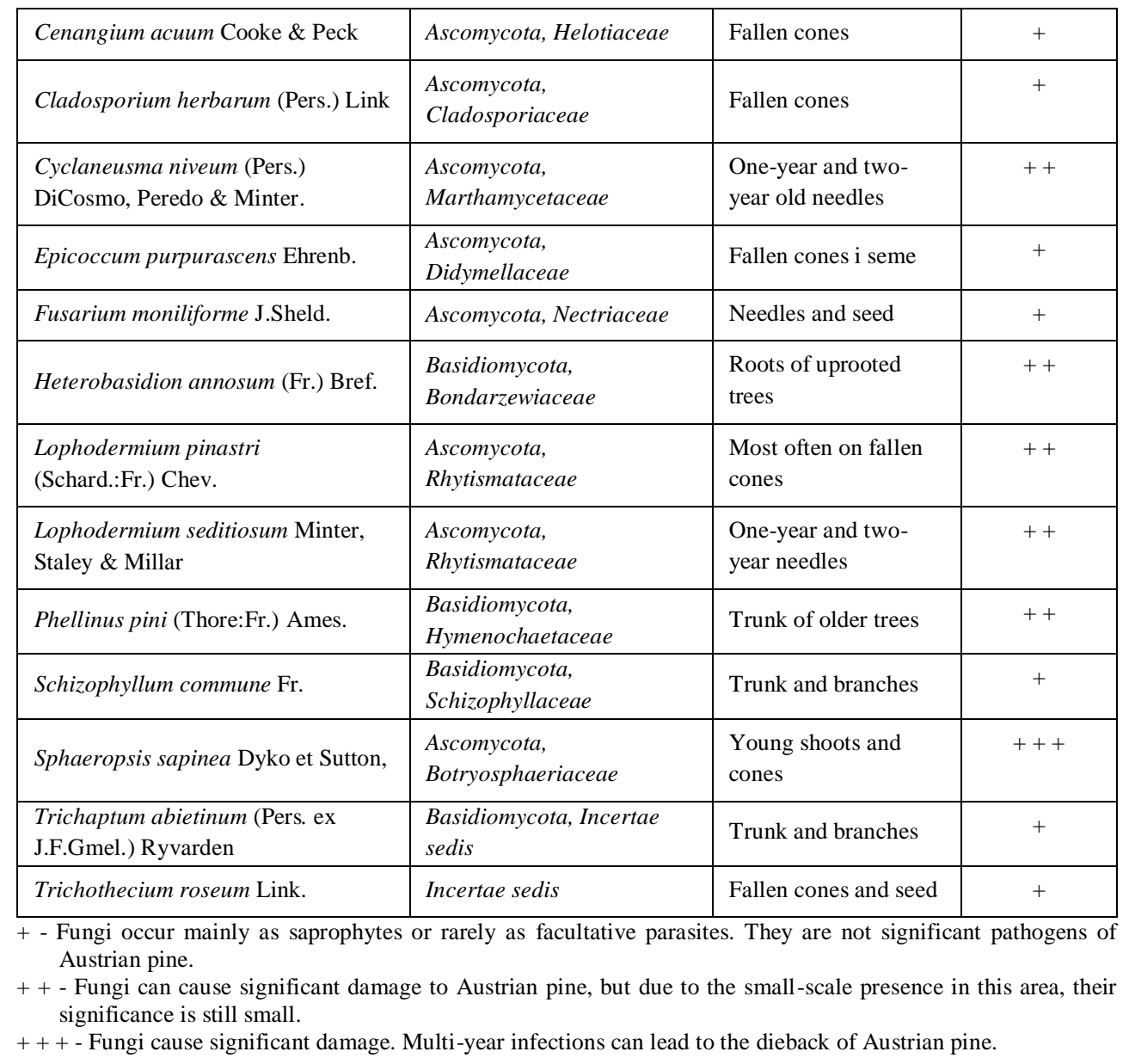

Two-year research in the area of Avala recorded the presence of 18 species of fungi on Austrian pine. Out of that number, 6 fungi were found on needles, 5 on needles and seeds, 2 on roots and stem bases, 1 on cones, 3 on trunks and branches, and 1 species in vascular bundles.

Of all the species, the most extensive damage is caused by Sphaeropsis sapinea and species of the Armillaria genus. The latter group includes the following species: Ceratocystis spp., Cyclaneusma niveum, Heterobasidion annosum, Lophodermium pinastri, Lophodermium seditiosum, and Phellinus pini. The other 10 species have very little significance and most often occur as saprophytes.

Species of the Armillaria genus are the most common causes of dieback and decay in coniferous and broadleaved cultures of all ages. Coniferous cultures established on the sites of broadleaved species are particularly affected, especially if the sites have not been previously destumped. This fungus lives on stumps as a saprophyte, and then as a parasite attacks weakened coniferous trees, or develops as a weak parasite on broadleaved trees.

Exploring the species diversity of the Armillaria genus Keča et al. (2006) found the following five species in Serbia and Montenegro: A. mellea, A. ostoyae, A. 
cepistipes, A. gallica, and A. tabescens. The most common species is A. gallica and A. tabescens the rarest.

S. sapinea colonizes young shoots and a severe attack usually leaves all shoots from the current growing season necrotic. A severe attack of this fungus was recorded in most compartments in the area of Avala. Perennial infections cause physiological weakness of trees, which leads to the dieback and eventually to the death of deformed trees.

Applying artificial inoculations of Pinus nigra seedlings, Milijašević, T. (2000) found that $S$. sapinea acts as a parasite. Uninjured shoots may be infected from April to August, although the symptoms of the disease are more difficult to notice in the summer months. This research indicates that the fungus can cause dieback of whole plants when it colonizes both the root collar and the root and forms fruiting bodies on them.

In our conditions, $C$. niveum has two infection periods. The first period is from late April to late August, and the second from mid-October to early December. Besides this species, C. minor, which occurs on Scots pine, is another species common in our country. Some authors consider species of this genus primary parasites, while some cite them as weak parasites or saprophytes. By artificial inoculations of two-year-old Scots pine seedlings, Karadžić, D. (1980) found that the infection is realized through stomata and then spreads in the mesophile. The first symptoms are noticed after three months, and and the apothecia begin to form four months after the inoculation. According to this research, C. minor acts as a parasite under controlled conditions.

According to Lazarev, V. (1980, 2004), the biology of Lophodermium species is characterized by 4 phases of development: the phase of infection, the phase of latency, the phase of transition to the saprophyting nutrition, and the phase of reproduction. The phase of infection is limited to the period of a mass release of ascospores, and penetration is possible through the cuticle or the stoma. The latency phase lasts 20-30 days and sometimes may be skipped. The phase of transition to the saprophyting nutrition is characterized by the formation of lush mycelium that spreads along the needle axis. It also spreads in the radial direction by filling resin ducts. Chlorotic spots become dark red, and the formation of pycnidia begins. At the end of this phase, the entire needle is necrotic and turns dark red. In the last phase, apothecia are formed. When mature, they open with a longitudinal crack and release ascospores. Transverse black or brown lines are also formed at this stage. Studying the degree of aggressiveness of Lophodermium species, Lazarev, V. (1981, 2004) found L. pinastri on older primary needles of seedlings in forest nurseries and stands, older secondary needles ( 2 and 3 years), and secondary needles attached to dead branches. L. seditiosum was found on younger primary needles of seedlings in forest nurseries, secondary needles of various ages, and most often on needles younger than one year in forest nurseries, cultures, and stands.

In the research of parasitic and saprophytic fungi in Austrian pine cultures in Serbia, Karadžić, D., Milijašević, T. (2008) found 41 species of fungi on Austrian pine, 45 species on Scots pine, while 24 species were found on both Austrian pine and Scots pine. Mycosphaerella pini, Sphaeropsis sapinea, Cenangium feruginosum, Gremmeniella abietina, and Armillaria spp cause the most extensive damage and dieback of Austrian pine trees. 
In the study of the pathogenic mycoflora of Pinus species, Karadžić, D., (1987) states that Scirrhia pini, Sphaeropsis sapinea, Cenangium feruginosum, and Gremmeniella abietina pose a practical problem in the establishment and maintenance of Austrian pine cultures, and perennial infections can lead to the dieback of trees. Heterobasidion annosum is also stated as a fungus that poses a practical problem in the establishment and maintenance of Austrian pine cultures and causes dieback.

H. annosum occurs less frequently on Austrian pine. In the area of Avala, it was observed on the lateral veins of one fallen tree in compartment 23 (section d). Another two species that can cause great damage to Austrian pine (Phellinus pini and Ceratocystis spp.) were found on individual (felled) trees, but have had no economic significance so far. $P$. pini occurs on old pine trees and considering Austrian pine, it attacks only trees over 100 years of age. The resistance of younger pines is explained by their greater ability to secrete resin. The resin quickly seals the injured places on the bark and thus prevents infections because the penetration of mycelium into the tree is prevented. The decaying process in the vertical direction progresses about $15 \mathrm{~cm}$ per year. The lower and central parts are most affected.

\section{CONCLUSIONS}

Based on two years of research, the following conclusions can be drawn:

- In the area of Avala, Austrian pine recorded the presence of 18 species of fungi. Out of that number, 6 fungi were found on needles, 5 on needles and seeds, 2 on roots and stem bases, 1 on cones, 3 on trunks, and branches and 1 species in vascular bundles

- Of all species, Sphaeropsis sapinea and species of the Armillaria genus cause the greatest damage. A severe attack of S. sapinea was recorded in most compartments in the area of Avala. Young needles of almost all shoots were infected. Species of the Armillaria genus were found on most decaying and dead Austrian pine trees. Austrian pine trees with common infections of $S$. sapinea, $C$. niveum and $L$. seditiosum are particularly endangered. These trees have a significantly decreased photosynthetic rate.

- Of other species, the presence of Phellinus pini should be noted. This species causes centre rot of old pine trees, with the lower and central part of the tree being affected most. In the area of Avala, it was found on several felled trees but has had no economic significance so far. However, with the increasing age of trees, greater damage can be expected.

- H. annosum was recorded in the area of Avala on the lateral veins of one fallen tree in compartment 23 (section d). This species poses practical problems in the establishment and maintenance of Scots pine cultures but it is not of great significance for Austrian pine. 
- Species that occur on cones and seeds (A. alternata, B. cinerea, E. purpurascens, $F$. moniliforme, and $T$. roseum) can cause significant damage only if the cones and seeds are improperly collected and transported, or improperly stored.

- Other species develop mainly as saprophytes or rarely as facultative parasites. They are not significant as pathogens of Austrian pine.

\section{REFERENCES}

Бондарцева, М. А. (1998): Определитель грибов России. Порядок Афиллофоровые, Вып.2, Наука, Санкт-Петерсбург, с.1-391.

Cvjetićanin R., Brujić J., Perović M., Stupar V. (2015): Dendrology. University of Belgrade, Faculty of Forestry, pp. 1-557.

Dennis, R. W. G. (1978): British Ascomycetes, J. Cramer, Vaduz, p. 1-585.

Ellis, M., B., Ellis, J., B. (1985): Microfungi on Land Plants. Croom-Helm, London, p. 1818.

Farjon, A. (2017): A Handbook of the World's Conifers. Volume I, Second, Revised Edition, Brill, p. 1154.

Karadžić, D. (1987): Effects of pathogenic mycoflora on decay and dieback of trees in Pinus species crops. Forestry No.5., pp. 89-106.

Karadžić D., Milijašević T. (2008): The most important parasitic and saprophytic fungi in Austrian pine and Scots pine plantations in Serbia. Bulletin of the Faculty of Forestry, No 97, p. 147-170.

Karadžić, D. (1980): Infection of Pinus Sylvestris by Naemacyclus minor. Proceedings of a Conference of the International Union of Forest Research Organizations, Working party on Needle diseases in Sarajevo, 15-19 September 1980, p. 5-8.

Keča, N., Bodles, W.J.A., Woodward, S., Karadžić, D., Bojović, S. (2006): Molecular-based identification and phylogeny of Armillaria species from Serbia and Montenegro. Forest. Pathology, No 36, p. 41-57.

Lanier, L., Joly, P., Bondoux, P., Bellemere, A. (1978): Mycologie et Pathologie Forestieres, Tome I, Pathologie Forestiere, Masson, Paris, 1-487.

Lazarev, V. (1980): Bioecological characteristics of Lophodermium species on two-needle pines in Bosnia. Plant Protection 151, Vol. 31 (1), Belgrade, pp. 5-28.

Lazarev, V. (1981): Intensity of Lophodermium species attack and disease development on seedlings of domestic provenances of Scots pine. Plant protection 155, Vol. 32 (1), Belgrade, pp.91-99.

Lazarev, V. (2004): Variability of Lophodermium species on pines. Bulletin of the Faculty of Forestry, pp. 9-41, Belgrade. 
Milijašević, T. (2000): Pathogenicity and control of the fungus Sphaeropsis sapinea Dyko \& Sutton - the agent of decay of Pinus species in Yugoslavia. Forestry 4-5, pp.73-85, Belgrade.

Minter W.D. (1981): Lophodermium on pines, Mycological Pap. 147, p.1-54.

Obratov-Petković, D., Đukić, M. (2000): Small flora of Avala. Agena, Belgrade, p. 1-129.

Sutton B.C. (1980): The Coelomycetes - Fungi imperfecti with Pycnidia, Acervuli and Stromata, Commonwealth Mycological Institute, Kew, p. 1-696.

http://www.indexfungorum.org/Names/Names.asp

\title{
NAJVAŽNIJE MIKOZE CRNOG BORA (PINUS NIGRA ARNOLD.) NA PODRUČJU AVALE
}

\author{
Zlatan RADULOVIĆ, Aleksandar LUČIĆ, Katarina MLADENOVIĆ, Ivan MILENKOVIĆ
}

\section{Rezime}

Istraživanja najvažnijih mikoza crnog bora na području Avale vršena su tokom 2018. i 2019 godine u 5 odeljenja i 11 odseka. Konstatovano je prisustvo 18 vrsta gljiva. Na četinama je konstatovano prisustvo 6 gljiva, na četinama i semenu 5, na korenu i pridanku 2, na šišaricama 1, deblu i granama 3 i u sprovodnim sudovima 1 vrsta.

Od svih vrsta najveće štete pričinjavaju Sphaeropsis sapinea i vrste roda Armillaria. Jak napad $S$. sapinea zabeležen je u većini odeljenja na području Avale. Inficirane su mlade četine na skoro svim izbojcima. Vrste roda Armillaria konstatovane su na većini stabala $\mathrm{u}$ fazi sušenja, kao i na već osušenim stablima crnog bora. Na nekim stablima su konstatovane zajedničke infekcije gljivama $S$. sapinea, $C$. niveum i L. seditiosum. Ova stabla imaju znatno redukovan fotosintetski potencijal. $H$. annosum predstavlja praktičan problem u podizanju i održavanju kultura belog bora i nema većeg značaja za crni bor.

Od ostalih vrsta treba ukazati na prisustvo gljive Phellinus pini. Ova vrsta za sada nema ekonomski značaj. Međutim, sa starošću stabala mogu se očekivati i veće štete. Vrste koje se javljaju na šišaricama i semenu mogu izazvati značajnije štete samo ako se šišarice i seme nepravilno sakupljaju i transportuju, ili nepravilno skladište. Ostale vrste se razvijaju uglavnom kao saprofiti ili retko kao fakultativni paraziti. Nisu značajni kao uzročnici bolesti na crnom boru.

\section{THE MOST IMPORTANT MYCOSES OF AUSTRIAN PINE (PINUS NIGRA ARNOLD.) IN THE AVALA AREA}

\author{
Zlatan RADULOVIĆ, Aleksandar LUČIĆ, Katarina MLADENOVIĆ, Ivan MILENKOVIĆ
}

\section{Summary}

The research of the most important Austrian pine mycoses in the area of Avala was performed during 2018 and 2019 in 5 compartments and 11 sections. The presence of 18 species of fungi was determined. Out of that number, 6 fungi were found on needles, 5 on needles and seeds, 2 on roots and stem bases, 1 on cones, 3 on trunks and branches and 1 species in vascular bundles.

Of all the species, the greatest damage is caused by Sphaeropsis sapinea and species of the genus Armillaria. A severe attack of $S$. sapinea was recorded in most compartments in 
the area of Avala. Young needles of almost all shoots were infected. Species of the Armillaria genus were found on most trees in the decaying phase, as well as on dead Austrian pine trees. Joint infections of $S$. sapinea, $C$. niveum, and L. seditiosum were found on some trees. These trees have a significantly decreased photosynthetic rate. $H$. annosum poses practical problems in the establishment and maintenance of Scots pine cultures but it is not of great significance for Austrian pine.

Other species whose presence should be noted include Phellinus pini. This species has had no economic significance so far. However, with the age of trees, greater damage can be expected. Species that occur on cones and seeds can cause significant damage only if the cones and seeds are improperly collected and transported, or improperly stored. Other species develop mainly as saprophytes or rarely as facultative parasites. They are not significant as pathogens of Austrian pine. 